\title{
THE MILITARY AND POLITICAL ASPECTS OF THE 1933 CUBAN REVOLUTION: THE FALL OF MACHADO
}

$7 \mathrm{HE}$ re-election of Gerardo Machado in 1928 promised to augur the continuity of the political quiescence that had characterized the President's first administration (1925-1928). By 1927, the Cuban chief executive had forged a coalition among the national political sectors, binding the Liberal, Conservative, and Popular parties to his candidacy for re-election. Through the appropriate application of patronage and coercion, the President had imposed a political consensus dissolving partisan autonomy, traditionally the source of anti-re-electionist violence. Cooperativismo, as the arrangement became known, conferred on parties outside the circumference of power the prerogatives, perquisites, and government posts inherent in the past only during national incumbency.

The Cuban President further solicited support for his re-election abroad. In early 1927, hoping for an endorsement from Washington, Machado explored his plans for another term with the Department of State. The American Minister in Havana urged the Secretary of State to reassure the Cuban President informally that the "Department would not be hostile to his reelection" in the impending national contest. ${ }^{1} \mathrm{~A}$ visit to the United States later that year provided Machado the opportunity to converse with the American President about the future of Cuban politics. President Coolidge tacitly approved Machado's plans for a second term, adding that the United States "only desired that the people of Cuba should have whatever Government and Constitution they themselves wanted."

By the late 1920's and early 1930's, the Cuban national order had begun to reveal the strain of economic dislocation and political discontent. In August, 1931, exiled leaders of old-line political parties attempted an invasion of the island in an effort to secure a beachhead long enough to in-

1 E.H. Crowder to Secretary of State, February 14, 1927, 837.00/2627, General Records of the Department of State, National Archives, Record Group 59 (Hereinafter cited as DS/NA,RG 59).

2 "Memorandum of Conversation," April 23, 1927, Unired States Department of State, Foreign Relations of the United States, 1927 (Washington, 1939), p. 527 (Hereinafter cited as FRUS). 
spire a national uprising against Machado. ${ }^{3}$ The still-born rebellion of 1931 , revealing the incapacity of the generation of independence to resolve the tensions with the Cuban political system, summoned into existence new groups to challenge the macbadista order. The new opposition leaders, reaching maturity in the Republic, consisted largely of urban professionals, frustrated politically by the monopoly of power exercised by the members of the independence generation. The ABC Revolutionary Society, the Organización Celular Radical Revolucionaria (OCRR), as well as women's resistance groups, university professors, and normal school students, all emerging in the aftermath of 1931, engaged on one level or another in the underground resistance against Machado. By the spring of 1933, the leading opposition factions had united into a Revolutionary Junta in New York calling for a revolution to remove Machado. ${ }^{4}$

By the early 1930's, the institutional controls with which the regime had sustained the machadista order showed signs of weakening. The traditional means of consolidating power, including patronage, political pressure, and fixed elections, were proving increasingly inoperative precisely because the new opposition sectors were unintegrated into the political system. The moment the government outlawed political change, appropriating the instrumentality capable of containing and expressing discontent, it reduced the level upon which the opposition could function, however ill-matched, to violence. Opposition violence necessitated a qualitative change in the means employed to retain power; sophisticated state controls yielded to institutional force. The government more and more entrusted its integrity to the ability of the military institution to restore the shattered machadista consensus.

Army functions expanded in direct proportion to the inability of national agencies to underwrite the continuity legitimacy of the constituted authorities. The prostration of the institutional order compelled national leadership to apply the armed forces to areas confined traditionally

${ }^{3}$ Alfredo Lima, La odisea de Río Verde (La Habana, 1934), pp. 9-10. Lt. Elwood R. Quesada, Acting Military Attaché, "Important Problems and Issues Requiring Governmental Recognition and Action," G-2 Report, August 14, 1931, File 2657-Q-330(63), Records of the War Department, General and Special Staffs, National Archives, Record Group 165 (Hereinafter cited as WD/NA, RG 165). Gerardo Castellanos G., Hacia Gibara (La Habana, 1933), pp. 284-285. Rubén de León, La origen del mal (Cuba, un ejemplo) (Miami, 1964), pp. 294-295. Lieutenant Elwood R. Quesada, Acting Military Attaché, "Armed Revolutionary Movement," G-2 Report, August 21, 1931, File 2657-Q330(64), DW/NA, RG 165. Raymond Leslie Buell, "The Cuban Revolt," Nerws Bulletin of the Foreign Policy Association, X (September 11, 1931), p. 1.

4 Lelend H. Jenks, "Cuba Faces a New Deal," in A. Curtis Wilgus (ed.), The Caribbean Area (Washington, D.C., 1934), p. 173. 
to civil authorities. The frequent and prolonged suspension of constitutional guarantees abrogated civil rights, facilitating government use of the armed institution. Military Supervisors displaced civilian political administrators; agents of the armed forces replaced provincial governors and municipal alcaldes throughout the island. Civilians accused of antigovernment activity were tried before military tribunals. In February, 1932, the administration amended the Military Penal Code to grant the army judicial authority over cases involving explosives, crimes against the military, destruction of sugar or cane machinery, and disruption of transportation and communication facilities. The revised Penal Code, moreover, required civil courts to surrender all such cases then pending to army tribunals. ${ }^{b}$ The creation of a National Militia in 1932 subjected the island's national, judicial, and secret police agencies to army jurisdiction; the government "militarized" municipal law enforcement agencies by appointing army officers as police chiefs. ${ }^{\circ}$ Virtually every government agency was under some form of military jurisdiction or review. In early 1933 army lieutenants and captains replaced civilian censors; ${ }^{7}$ all members of the armed forces received authority to investigate and arrest individuals suspected of anti-government activity. By 1933, the armed institution had emerged as the single most important underpinning of the beleaguered Machado government.

Growing civil reliance on the military to underwrite the integrity of the political order enabled the armed institution to exact certain privileges and immunities. In January, 1932, all members of the armed institution were exempted from civil prosecution, subject only to military justice. The institutional integrity of the armed forces remained virtually intact while the government, struggling to remain solvent during the worst months of the depression, slashed national expenditures. In July, 1933, the army consisted of some 12,000 officers and men. ${ }^{8}$ The Department of War appropriations consumed nearly 20 percent of the national budget; the actual cost of the armed institution, in fact, was suspected to

${ }^{5}$ Harry F. Guggenheim to Secretary of State, February 18, 1932, 837.00/3230, DS/NA, RG 59.

6 "El caso de Zubizarreta," Bobemia, XXVI (4 febrero de 1934), p. 20. Major J.J. O'Hare, Military Attaché, "Important Problems and Issues Requiring Governmental Recognition and Action," G-2 Report, July 26, 1932, File 2657-Q-330(130), DW/NA, RG 165. Harry F. Guggenheim to Secretary of State, March 5, 1932, 837.00 General Conditions/50, DS/NA, RG 59.

${ }^{7}$ Harry F. Guggenheim to Secretary of State, February 7, 1933, 837.00 General Conditions/58, DS/NA, RG 59.

${ }^{8} \mathrm{~J}$. Martínez, Capitán, Estado Mayor, Jefe de la Sección de Personal y Ordenes, "Relación numérica de oficiales y alistados del ejército, existentes en 31 de julio de 1933," File 2012-153(2), DW/NA, RG 165. 
be several million dollars in excess of published budgetary figures. ${ }^{9}$ While the government reduced salaries, released thousands of public employees, permitted pay schedules to fall hopelessly in arrears, and while tens of thousands of Cubans suffered the full impact of the depression, soldiers were reported "enjoying unheard-of luxury."10 Political realities mitigated economic wisdom. Administration leaders admitted privately fears that army reductions would encourage retired officers to join the opposition groups. ${ }^{11}$

The application of the military against the opponents of the government produced a doctrinal anti-militarism among the sectors of the opposition. The army had moved into a buffer position between the administration and its foes, emerging as the apparent agent of repression. The extraordinary expenditures devoted to "national defense," moreover, particularly unpalatable during the depression, led to a generalized reexamination of the proper relation of the armed institution to Cuban national life. Opposition sectors demanded restructuring the armed forces. The military institution, the $\mathrm{ABC}$ protested, had developed into a political instrument designed to underwrite "presidential imposition," perpetuating crimes against the population to defend an unpopular government. The ABC demanded the "demilitarization" of the Rural Guard, the suppression of privileges which placed the army above the law, and the instituting of obligatory military service to remove politics from the army. ${ }^{12}$

Old line politicians also attacked the privileged position of the military. One Liberal legislator complained that government policies had "enthroned" militarism on the island, protesting the misdirected priorities in which a hospital patient received fifteen cents a day while an army mule was allocated fifty cents. ${ }^{13}$ Cosme de la Torriente, one of the most prestigious members of the independence generation, attacked military expenditures and expressed dismay over the use of the armed forces against civilian opposition factions. ${ }^{14}$

9 "Cuban Budgetary Appropriations for Army and Navy, 1902-1934," Appendix No. 2, in Lieutenant Colonel C.K. Nulsen, to Military Attaché, Havana, Cuba, July 5, 1934, File 2012-153(2), DW/NA, RG 165.

${ }^{10}$ New York Times, III, January 4, 1931, p. 6. Cf. Edelmira González, La revolución en Cuba. Memorias del coronel Rosendo Collazo (La Habana, 1934), pp. 39-40.

11 Lieutenant Colonel T.N. Gimperling, Military Attaché, "Strength and Composition," G-2 Report, April 27, 1933, File 2012-119(11), DW/NA, RG 165.

12 Carlos G. Peraza, Machado, crímenes y borrores de un régimen (La Habana, 1933), Pp. 234-235.

13 Carlos Manuel de la Cruz, Proceso histórico del machadato (La Habana, 1935), PP. 352, 358-359.

14 Cosme de la Torriente, Cuarenta años de mi vida, 1898-1938 (La Habana, 1939), p. 207. 
Army duties during the last years of the machadato and suspension of the national charter to permit the armed institution to discharge its new responsibilities unhampered had placed the army forces in a privileged relationship to society. The military served a government, expanding its authority and privileges, while combating a body politic determined to reduce army influence in national life. The army was compelled to oppose any political movement potentially pernicious to the corporate integrity of the armed institution, a requirement transcending, in fact, any commitment to the incumbent political authority. Henceforth any change in the political order was a source of vital concern for the armed institution. The military had secured its expanded influence under a government whose very legitimacy a host of politically ambitious opposition factions repudiated and during a period in which the Constitution was suspended the large portion of the time. In short, military preeminence extended well beyond legal limitations and institutional sanctions and found sustenance only in the Machado government; by extension, the threat to the machadista order involved inextricably the fate of the armed institution.

By 1933 Cuban instability necessarily involved the United States. The Cuban Ambassador in Washington warned the new Democratic administration that the beleaguered Machado government required immediate support, "otherwise chaos would result, the sort of chaos that might easily require the United States to intervene in a military way."1s In early May, 1933, the Roosevelt administration outlined a tentative policy approach to help relax political tensions on the island. The administration instructed the new Ambassador to Cuba, Sumner Welles, to offer the "friendly mediation" of the United States government. Secretary of State Cordell Hull hoped negotiations would lead to a "definite, detailed, and binding understanding between the government and leaders of the opposition factions." 16

The arrival of the new Ambassador in Cuba had immediately a salutary impact. The government pledged constitutional reforms, lifted censorship, and released a host of political prisoners. By the end of June, the Cuban government and the large portion of the opposition sectors, including the $A B C$, the OCRR, women's opposition groups, and normal school instructors, had agreed to participate in the projected negotiations.

The mediation sessions opened auspiciously on July 1, 1933. Within

\footnotetext{
15 William Phillips, "Memorandum of Conversation with Cuban Ambassador," May 4, 1933, 550.S.I. Washington/415, DS/NA, RG 59.

${ }^{16}$ Secretary of State to Appointed Ambassador in Cuba, May 1, 1933, FRUS, V, 1933, p.
} 285. 
several days, the government released additional political prisoners; on July 6, Machado guaranteed the safety of participating factions during the course of the mediations, extending protection to a thirty-day grace period should the mediations have failed. ${ }^{17}$ Opposition leaders, in turn; pledged to halt anti-government activity for the duration of the negotiations.

The American Ambassador entered the mediations with very specific ends. Welles sought to arrive at a conciliation permitting "absolutely fair and uncontrolled elections" in the autumn of 1934, an arrangement predicated on Machado's agreeing to shorten his term by one year. ${ }^{18}$ Before leaving Washington for Havana, the Ambassador had expressed his desire to replace Machado before the President completed his term, or at least during the electoral period, with someone in whom all the political factions had confidence. ${ }^{19}$ By mid-July, Welles predicted confidently that the Cuban President would accept his proposal. ${ }^{20}$

The public announcement of the Ambassador's proposal during the course of the negotiations shattered the mediations. The negotiation suggestions, articulated by the American Ambassador, immediately produced a re-alignment of power factions on the island. Sensitive to the political repercussions of Welles's proposal, the Cuban President quickly repudiated the propositions asking him to reduce his term, declaring that he was under no obligation to accept the proposals of a mediator lacking an official position in the negotiations; Machado attempted to demonstrate that Welles acted as a disinterested individual, not the official American representative. Within several days Machado's position became untenable when the Department of State announced that the American Ambassador had, in fact, acted with the full approval and support of the United States government. ${ }^{21}$

In the following days, Welles labored to undermine the President's domestic position, hoping in this fashion to force Machado to accept the mediation proposals. The American Ambassador first assailed the political foundations of the machadista order. Cooperativista parties foresaw accurately the inevitable climax of a confrontation between Machado and the American Ambassador. It was incumbent upon the leaders of the

17 Charles A. Thomson, "The Cuban Revolution: Fall of Machado," Foreign Policy Reports, XI (December 18, 1935), p. 253.

18 Sumner Welles to Secretary of State, May 13, 1933, FRUS, V, 1933, p. 288. Sumner Welles to Franklin D. Roosevelt, July 17, 1933, FRUS, V, 1933, p. 324.

19 Sumner Welles to Franklin D. Roosevelt, May 18, 1933, Official File 470, Sumner Welles, Franklin D. Roosevelt Papers, Hyde Park, New York.

${ }^{20}$ Sumner Welles to Franklin D. Roosevelt, July 17, 1933, FRUS, V, 1933, p. 324.

21 New York Times, July 27, 1933, p. 1. 
Conservative, Liberal, and Popular parties, seeking to guarantee the integrity of their respective organizations in post-Machado Cuba, to be party to the final solution. If Machado fell solely through American pressure, old line political parties, already discredited by their long cooperativista posture, faced the prospect of drastic reorganization, at best, or complete suppression-as many opposition factions demanded. The success of a revolution against the cooperativista order likewise threatened the old party structure, subjecting macbadista collaborators to the reprisals of the new political organizations. Joining the American Ambassador, however, carried the implicit assurance the parties would survive the machadato. In early August, Welles reported with some satisfaction that the Liberal Party, "for the first time" since Machado's election, had "summoned up sufficient courage to dictate to the President" and was "not being dictated [to] by him.".22 Several days later, the leaders of the Conservative, Liberal, and Popular parties accepted the mediator's proposal, preparing to act in Congress to expedite Machado's departure. ${ }^{23}$ The Popular Party, Welles reported, endorsed the suggestion as a means "to reestablish moral peace among Cubans."24 At the same time, the Conservative Party called upon the President to retire as an "act of the highest nobility."25

The American Ambassador also assailed the diplomatic foundations of the macbadista order. Unsettled internal conditions provided the United States Minister with the pretext with which to threaten the withdrawal of American support; within the context of the Platt Amendment, Machado had simply failed to maintain a government "adequate for the protection of life, property and individual liberty." The Cuban President proved incapable of restoring stability and order. As early as 1931, the political warfare on the island had defied the government's best efforts to maintain tranquility. ${ }^{26}$ And in early August, 1933, political discontent, fusing with economic grievances, had culminated in a general strike, paralyzing the island. On August 9, the Ambassador concluded:

1. There is absolutely no hope of a return to normal conditions in Cuba as long as President Machado remains in office. No one other than the small clique of officeholders surrounding him has any trust or con-

22 Sumner Welles to Acting Secretary of State, August 5, 1933, 837.00/3603, DS/NA, RG 59.

23 Sumner Welles to Secretary of State, August 7, 1933, 837.00/3606, DS/NA, RG 59.

24 Sumner Welles to Secretary of State, August 9, 1933, 837.00/3626, DS/NA, RG 59.

25 Sumner Welles to Secretary of State, August 10, 1933, 837.00/3630, DS/NA, RG 59.

${ }^{26}$ Lieutenant Elwood R. Quesada, Acting Military Attaché, "Banditry, Riots and Similar Infractions of Public Peace and Safety," September 3, 1931, 837.00 Revolutions/56, DS/NA, RG 59. 
fidence in him and he represents in his person to every other Cuban the cause of economic distress and personal suffering which has existed during the past 3 years.

2. So long as this condition continues here there is no possible chance of improving economic conditions in Cuba, and there will be immense loss to the Cuban people themselves and as a natural corollary to all the American interests doing business in or with Cuba. ${ }^{27}$

Welles proposed to withdraw American recognition if, at the end of a reasonable period, Machado continued to reject the mediator's proposal; this would obviate, Welles predicted, the need for an armed intervention, making it impossible for Machado to remain in power more than a short period. ${ }^{28}$ The American Ambassador further intimidated the Cuban President by alluding to the obligations of the United States under the Permanent Treaty, indicating that the purpose of his mission was to avoid the necessity of an armed intervention. ${ }^{2 \theta}$

The Cuban President seized upon this thinly veiled threat of intervention as the issue around which to attempt to mobilize national support. President Machado would not, the Cuban Ambassador in Washington informed the State Department, be "pushed out" by the United States. ${ }^{30}$ In Cuba, Machado denounced American meddling in Cuban affairs. Recalling his service to the Republic during the war for independence, the President indicated bluntly that he preferred armed intervention to the acceptance of the mediator's proposals, ${ }^{31}$ exhorting his countrymen to defend the homeland against the North American invaders. ${ }^{32}$ The Cuban President further appealed to the court of Latin American public opinion, asking the Western Hemisphere to condemn United States intervention in Cuba. ${ }^{83}$

Welles and Machado struggled against a backdrop of national tensions growing increasingly acute. The general strike continued to deepen the crisis, raising the spectre of profound social and political dislocations. A

27 Sumner Welles to Secretary of State, August 9, 1933, 837.00/3622, DS/NA, RG 59.

28 "I do not believe that the withdrawal of recognition would in all probability force us to intervene," Welles suggested. "I think that if the President himself was advised that we would withdraw recognition unless he accepted a fair solution of the problem, he would be obliged to accept such solution by most members of his Cabinet, by the Army and by the great majority of Congress." Sumner Welles to Secretary of State, August 8, 1933, 837.00/3616, DS/NA, RG 59.

29 Sumner Welles to Secretary of State, August 7, 1933, 837.00/3606, DS/NA, RG 59.

80 "Memorandum by the Under-Secretary of State," August 8, 1933, 837.00/3629, DS/ NA, RG 59.

81 Sumner Welles to Secretary of State, August 8, 1933, 837.00/3616, DS/NA, RG 59. New York Times, August 9, 1933, p. 12.

32 New York Herald Tribune, August 8, 1933, p. 2.

33 Sumner Welles to Secretary of State, August 10, 1933, 837.00/3633, DS/NA, RG 59. 
between strikers and government forces further crystallized the political content of the movement. By August 7, Havana was paralyzed. ${ }^{34}$

Almost two weeks after the Ambassador had submitted his original proposal, Welles devised a "new solution." On August 11, Welles reported having a "confidential talk" with Secretary of War General Alberto Herrera in which the former Army Chief of Staff pledged to support the Ambassador's new proposition. Welles's newest project permitted the President to present a counterproposal, thereby saving face by ostensibly accepting a plan of his own making. Machado's counterproposal embodied the substance of Welles's earlier suggestion; the President was to request a leave of absence, accepting the resignation of all cabinet members except General Herrera, who thereupon became acting President. $^{.5}$

By offering General Herrera the presidency, the American Ambassador apparently deliberately invited the armed forces to impose the political settlement continuing to elude his best efforts. Surely Welles must have realized that the former Army Chief's only leverage with which to make any contribution to the "new solution"-certainly a contribution of sufficient magnitude to warrant naming Herrera President-lay entirely in the armed institution. The participation of the Secretary of War, Welles predicted confidently, insured "the loyal support of the Cuban Army," which was "unanimously devoted" to the former Chief of Staff. ${ }^{38}$ Thus one political analyst in Washington could write that Welles reported "before Machado himself knew it, that the army was about to desert the Cuban president." 37

On August 12, the armed forces turned against the Cuban President. The major military installations in Havana, including Camp Columbia and La Cabaña, and the Aviation Corps, informed Machado they could no longer support his administration.

Direct military intervention responded in many ways to the position of apparent powerlessness-and the concomitant vulnerability in that impotence-in which the armed institution perceived itself. As the balance of power tipped against the administration, the military, marginal observers of the midsummer events, found the alternate solutions unacceptable. In each instance, the fate of the military establishment hinged on a political settlement over which the military lacked effective control:

34 Gerardo Castellanos G. Panorama bistórico (La Habana, 1934), pp. 1539-1540.

${ }^{35}$ Sumner Welles to Secretary of State, August 11, 1933, 837.00/3640, DS/NA, RG 59. 36 lbid.

37 Arthur Krock, "Hull Wins Spurs in Test of State Department in Cuba Crisis," New York Times, August 21, 1933, p. 16. 
the spectre of an American intervention, the likelihood the mediator would attempt to impose a political settlement pernicious to the armed forces, and the prospect of a social upheaval resulting from the general strike represented unsatisfactory solutions to the political crisis.

The military action of August 12 was a reaction to the apparent imminence of United States intervention. The armed forces shrank in horror at the spectacle of Machado defying American military and political pressure, haranguing the population to defend the island against the anticipated intervention, and appealing to Latin American public opinion to condemn Washington. The "sole purpose" of the army movement, one military spokesman announced, "was the avoidance of American intervention." ${ }^{88}$ An intervention to displace Machado would have inextricably involved the army, undoubtedly leading to a reduction, if not the suppression, of the military institution. ${ }^{39}$ As early as July 25 , Welles had informed Herrera that he had obtained authority from President Roosevelt to land Marines. ${ }^{40}$ To have disclosed this far-reaching authority to the former Chief of Staff was, in effect, intimating the inevitability of an armed intervention unless Cubans arrived at a solution consistent with the Ambassador's proposals. The armed forces acted to remove the potential precipitant of intervention-in this instance, the Cuban President himself. Military leaders, in fact, invested the August 12 golpe with the noblest objectives, suggesting that army non-involvement would have been tantamount to treason for it would have permitted American troops to violate Cuban national sovereignty.11

Army commitment to the constituted government was operative only as long as that administration retained the means with which to preserve the integrity of the military institution. This meant necessarily government control of the instrumentality regulating political change. The support that the Platt Amendment invested in the constituted order, guaranteeing political continuity, exerted a powerful counterpoise assuring army loyalty. Within this context, the American Ambassador under-

38 New York Times, August 12, 1933, p. 1.

39 Thomson, "The Cuban Revolution: Fall of Machado," p. 257. New York Times, August 7, 1933, p. 7. Alberto Lamar Schweyer, Como cayó el presidente Macbado (Madrid, 1934), pp. 179-180.

40 Under-Secretary of State William Phillips, "Memorandum of Conversation with

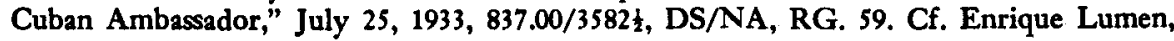
La revolución cubana (México, 1934), p. 78.

11 Gonzalo de Quesada y Miranda, 'En Cuba Libre! Historia documentada y anecdóctica del macbadato (2 vols., La Habana, 1938), II, Pp. 243-244. Horacio Ferrer, Con el rifle al hombro (La Habana, 1950), pp. 321-322. Orestes Ferrera, "Los últimos días del régimen de Machado," Bobemia, XXXXIX (Agosto 10 de 1952), p. 114. 
mined Machado's domestic position vis-á-vis the armed forces when he recommended the President shorten his term by one year. Indeed, this announcement must be viewed as nothing less than a deliberate and calculated maneuver designed to force Machado to accept the mediator's recommendations. Welles possessed sufficient insight into the subtleties of Cuban politics to appreciate the repercussions this proposition would have on the incumbent government. In June, 1933 Welles the Ambassador, using personal diplomacy to persuade Machado to retire early, guarded his proposal carefully, fearing a premature disclosure would "weaken" the President's control over congress and the armed forces. ${ }^{42}$ Welles the mediator, by revealing the withdrawal of American support for the President, precipitated a realignment of alliance, releasing $\mathrm{Ma}$ chado's supporters to seek the most efficacious means with which to protect their interests long vested in the collapsing macbadista order.

The tenor of the mediations likewise had failed to inspire the confidence of the military establishment in the factions competing to substitute for Machado. Opposition sectors articulated programs designed to reform the armed forces. The $\mathrm{ABC}$, for example, advocated reducing the military institution, restricting army authority, and abrogating the military law of $1932 . .^{43}$ Rumors during the negotiations likewise had a disquieting effect on army leaders. One report suggested that the opposition planned to reduce the army from 11,000 to 3,000 officers and men; business and professional groups, agitated by the excessive taxation necessitated by the large military appropriations, similarly endorsed the reduction of the military institution. ${ }^{44}$ One macbadista official later speculated that the armed forces, had they remained passive, would have been at the "mercy of the triumphant revolution made by the Ambassador" if the mediation had been successful in ousting Machado. ${ }^{45}$

The opposition's anti-military projects, threatening the corporate integrity of the armed forces thus further animated the armed forces to act to prevent a political settlement injurious to the military institution. Participation in the mediations had conferred legitimacy on the former illegal opposition organizations, virtually guaranteeing the sectors which the army had harried during the preceding years positions of responsibility 59.

42 Sumner Welles to Acting Secretary of State, June 6, 1933, 837.00/3537, DS/NA, RG

13 ABC, El ABC en la mediación (La Habana, 1934), pp. 46-48. Ricardo Adam y Silva, La gran mentira. 4 de septiembre de 1933 (La Habana, 1947), p. 67.

44 Lieutenant Colonel T.N. Gimperling, Military Attaché, "Causes of Recent Revolt of Armed Forces Against Machado," G-2 Report, August 21, 1933, File 2012-133(7), DW/ NA, RG 165.

45 Lamar Schweyer, Como cayó el presidente Macbado, pp. 179-180. 
in the post-Machado political order. The armed forces, in short, had a powerful vested interest in the course of the mediations but lacked direct influence to affect the outcome of the negotiations. It was incumbent on the military to intersect somewhere the trajectory of the rising power of the opposition to retain sufficient authority to preserve the institutional integrity of the armed forces. To have remained on the fringes of national decisions as passive onlookers would have inevitably placed the armed forces at the mercy of the subsequent government, likely to be composed of former army foes. Machado later attributed the military defection to fear of seeing enemies of the government triumph, intervening to offset the anticipated action against the armed institution. ${ }^{46}$ By participating in the transfer of power, the armed institution protected its own corporate integrity by favoring a political continuity not inimical to the interests of the armed forces.

The army intervention of August 12 was not unconditional. Military commanders acted only after having secured from opposition leaders a guarantee, to which the American Ambassador subscribed, that the subsequent government would respect the integrity of the armed forces. A "strictly confidential" memorandum, couched in Machado's counterproposal, pledged that the armed forces of the state would be "maintained without any alteration" until May 20,1935, the scheduled expiration of Machado's second term. The proviso further stipulated that "members of the said armed forces ... cannot be removed from their positions nor punished" in any way inconsistent with the existing laws. ${ }^{47}$ The military institution, before agreeing to support the projected political settlement, had thus guaranteed the preservation of its integrity.

The armed forces acted on August 12 also in response to the shadow of social upheaval cast by the general strike. Welles later indicated that the "ominous signs provided by a paralyzing strike" necessitated a. "radical solution" of the Cuban problem to "forestall the cataclysm which otherwise was inevitable." 48 At least one leader of the military movement perceived the August general strike as "revolutionary" in its intent." By the first week of August, one correspondent in Havana described the situation as "a race between mediation by the United States Ambassador

${ }^{46}$ Gerardo Machado to Franklin D. Roosevelt, September 4, 1933, Official File 150, Cuba, 1933-1934, Box 2, Roosevelt Papers.

47 "Memorandum," 11 de agosto de 1933, in Orestes Ferrara to Sumner Welles, August 12, 1933, File (1933) 800, American Embassy, Cuba, Correspondence, Foreign Service Posts of the Department of State, Record Group 84.

48 Sumner Welles, Two Years of the "Good Neighbor Policy," Department of State, Latin American Series No. 11 (Washington, D.C., 1935), pp. 8-9.

49 Ferrer, Con el rifle al hombro, p. 316. 
and open revolution."50 Such considerations undoubtedly motivated Welles to contact General Herrera to implement the "radical solution"; however anxious the American Ambassador may have been to depose Machado, Welles's means had remained consistently constitutional, orderly, and, above all, controlled. The strike represented an act beyond control, raising the spectre of "open revolution."

On August 12, Machado duly requested his leave of absence. The dramatis personae, observing the best constitutional forms in accordance with Welles's plan, acted out the change of government. In the early hours of August 12, army leaders rejected Herrera's appointment as President, necessitating a modification of the plan. ${ }^{51}$ Otherwise, the new administration assumed power very smoothly. All machadista cabinet members, except Herrera, resigned; the Secretary of War was inaugurated Provisional President and immediately appointed Carlos Manuel de Céspedes Secretary of State. Herrera then resigned, permitting Céspedes to assume the presidency. The architects of the Machado-HerreraCéspedes turnover planned an orderly, constitutional transfer of power. So smooth, in fact, was this transition, the Secretary of State Hull noted that it was not necessary to grant the Céspedes administration "formal recognition since that government had been achieved by constitutional processes." ${ }_{22}$

Behind the ostensible survival of "constitutional processes," however, lay the new reality of Cuban national politics. For the first time in the history of the Republic, the armed forces had intervened directly to impose a political settlement on civilian political sectors. Despite the quick restoration of civilian authority, the military debut of August 12 established a precedent; the armed forces learned the facility with which the frail civilian order could be displaced. Between August 12, 1933 and 1940 , the army intervened directly in national politics no less than four times to displace civilian executives. Military interventions during the 1930 's inured the Cuban body politic to the presence of the armed forces in national politics, establishing the praetorian tradition that would characterize the national order in the 1950's.

University of Soutb Florida

Louis A. Pérez, Jr.

Tampa, Florida

50 New York Times, August 7, 1933, p. 7.

51 Jorge Quintana, "Fué el 12 de agosto de 1933," Bobemia, XXXXI (Agosto 4 de 1949), p. 98.

52 Cordell Hull, The Memoirs of Cordell Hull (2 vols., New York, 1948), I, p. 314. 